\title{
Dünya Ticaret Örgütü’nün Çevre Koruma Politikaları
}

\author{
Seçil Gül MEYDAN YILDIZ* Hayriye ŞENGÜN**
}

\begin{abstract}
$\ddot{O} Z$
Kalkınma stratejilerinin doğal kaynaklar üzerinde yarattı̆̆l, olumsuz etkilerin biyosferin ekolojik dengesini bozması ve bu durumdan gelişmiş veya gelişmekte olan tüm ülkelerin etkilenmesi, ekonomik gelişme politikalarında, tüm devletlerin toplumsal, ekonomik, çevresel ve kültürel olarak ortak bir dil ortaya koyması ve önlemler oluşturulması bir zorunluluk haline gelmişstir. Uluslararası çevre koruma politikalarının tarihsel gelişimi içerisinde, uluslararası ticaretin serbestleşmesi ile küresel düzeyde artan kirlenme arasındaki ilişkinin çevre politikalarının gelişimiyle koşut bir süreç izlediği gözlenmektedir.

Neoliberal politikalar ve küreselleşme sürecinin etkisiyle gelişmiş ülkelerin ticaret ve çevre konularını birlikte ele almalarında Çok Taraflı Yatırım Anlaşması (MAI)'nın düzenlemeleri temel unsur olmaktadır. Bu çalışmada, ekonomi sektörünün temel bileşeni olan ticaret politikasl ve Dünya Ticaret Örgütü'nün (DTÖ) Türkiye'de oluşturduğu yeni politikalar ve yapılanmalar literatür taraması yöntemiyle açıklanmaktadır. DTÖ bünyesinde yapılan sözleşmeler ana hatlarıyla incelenerek, çevrenin korunmaslyla ilgili alınan önlemler DTÖ kuruluş görevleri kapsaminda açıklanmaktadır.
\end{abstract}

Anahtar Kelimeler: Çevre, Çevre Sorunlarl, Ticaret, Dünya Ticaret Örgütü

JEL Sinıflandırması: Q56

\section{Environmental Protection Policies Of World Trade Organization}

\begin{abstract}
Due to the fact that the unfavorable effects of the development strategies on the natural resources disturb the ecological balance of the biosphere and all developed and developing countries are affected from this situation, it has become a necessity in the economic development policies for all countries to present a common language socially, economically, environmentally and culturally and take necessary measures. During the historical development of the international environmental policies, it draws attention that the liberalization of the international trade and the development of the environmental policies in conjunction with the global pollution follow a parallel process.

Regarding the developed countries dealing with the trade and environmental issues together with the effect of neoliberal policies and globalization process, the Multilateral Agreement on Investment (MAI) becomes the main factor. In this study, the commercial policy which is the fundamental component of the economy sector and the new policies and structures established by the World Trade Organization (WTO) in Turkey are clarified by literature review method. The contracts drawn up within the body of WTO are examined and the environmental protection measures are explained within the scope of the establishment tasks of WTO.
\end{abstract}

Key Words: Environment, Environmental Problems, Trade, World Trade Organization.

JEL Classification: Q56

\footnotetext{
* Dr. Öğr. Üyesi, Bozok Üniversitesi Mühendislik Mimarlık Fakültesi, Şehir ve Bölge Planlama Bölümü. secilmeydan@gmail.com

** Doç. Dr., Bayburt Üniversitesi, İktisadi ve İdari Bilimler Fakültesi, Kamu Yönetimi Bölümü.

hayriyesengun@gmail.com
} 


\section{GİRIŞ}

Temelleri 16. yüzy1la kadar uzanan Sanayi Devrimi'nin toplumsal ve ekonomik yapıda yarattığı köklü değişimler, yaşam standartlarını etkileyerek tüketim odaklı bakış açısının hayatın her alanında yer bulmasına neden olmuştur (Meydan Yıldız, 2016). Yaşamın merkezinde yer alan tüketme alışkanlıkları, canlı varlığını ve sürekliliğini doğrudan ve dolaylı olarak etkileyen çevre sorunları olarak karşımıza çıkmaktadır. Çevresel sorunlar, başlangıçta hem etkileri sınırlı ve bölgesel sayılmasından hem de ekonomik büyümenin gelişmiş ülkeler tarafindan öncelikli hedef olarak kabul edilmesinden ötürü çözülmesi gerekli bir sorun olarak görülmemiştir. Oysa bilimsel ve teknolojik gelişmelerin ve uluslararası çalışmaların etkisiyle, küresel bir bilinçlenme eylem ve politikaları hız kazanmıştır. İklim değişikliğinin etkileriyle, endemik türdeki flora ve faunanın, meraların ve orman alanlarının tükenme tehlikesiyle karşı karşıya kalması çevre sorunlarının basit bir kirlenme olmadığının ve bu sorunların çevre ve kalkınma arasındaki etkileşimden kaynaklanan karmaşık bir sorun olduğunun uluslararası ölçekte kabul edilmesini sağlamıştır. 1960'lı yıllardan sonra çevreye yönelik kaygılar ulusal ve uluslararası gündemi sürekli meşgul etmeye başlamıştır. Dünyanın çevreyle ilgili gündemini önceleri ekonomik gelişmelerin çevre üzerindeki baskısına ilişkin endişeler oluştururken, daha sonraları ekolojik baskıların ekonomik beklentiler üzerindeki etkileri de kaygı unsuru olmaya başlamıştır.

Küresel düzeyde ticari faaliyetlerin serbestleşmesi ve ekolojik krizler ile paralel olarak gelişen çevre politikaları bu sürecin önemli ögesi haline gelmiştir. II. Dünya Savaş1 sonrasında, 1948'de "Gümrük Tarifeleri ve Ticaret Genel Anlaşması" (GATT) dünya ticaretine yeniden yön verme stratejisiyle yürürlüğe girmiştir. GATT'ın temel amacı, dış ticaret yapısını serbestleştirerek bu süreçte engel teşkil eden gümrük vergilerinin azaltılması ve tarifeye dönüştürülmesidir. Aynı zamanda, "olabilecek diğer engellemelerin ve farklı işlemlerin kaldırılması yoluyla dünya ticaretinin serbestleşmesinin sağlanmasıdır" (İktisadi Kalkınma Vakfi, 1998: 8). Neoliberal politikalar ve küreselleşme sürecinin etkisiyle gelişmiş ülkelerin ticaret ve çevreyi birlikte düşünen, ticaretin bir aktörü olarak çevreyi gören yaklaşımları, Çok Taraflı Yatırım Anlaşması kural düzenlemelerinin temel unsuru olmaktadır. Dünya Ticaret Örgütü’nün temel fonksiyonları i) DTÖ anlaşmalarının uygulanmasını ve idaresini sağlamak, ii) müzakereler için bir forum ortamı sağlamak ve anlaşmazlıkların çözümü için bir mekanizma oluşturmak, iii) çevresel amaçlar için kullanılan ticari tedbirlerin ve ticari etkisi olan çevre politikalarının şeffaflığına ilişkin ticaret kurallarını belirlemek, olarak özetlenebilir (WTO Dispute Settlement, 2018).

Ticaret, yaşam refahını artırmak için kullanılabilecek zenginliği yaratmaktadır. Böylece, çevresel gelişim için kullanılabilecek kazanımlar aracılı̆̆ıyla yenilenebilir enerji kaynaklarının etkin kullanımı ve daha az atığın oluşmasını sağlayacak geri dönüşüm sistemlerinin kurulması sağlanırken, çevre dostu teknolojilere erişimin kolay olduğu bir ticaret sistemi oluşturulabilmektedir. 
Dünya Ticaret Örgütü tarafından ortaya konulan ilkeler tüm ülkelerin uyum sağlayabileceği güçlü kurallar sistemi olarak tanımlanmaktadır. Nitekim DTÖ kuralları küresel rekabet piyasasında yer alabilme açısından oldukça önemlidir. Küresel rekabet piyasasından uzak bir ticaret anlayışı ulusal piyasaları muhafaza ederken yerli tüketicileri daha yüksek fiyat ödemeye, yoksullaştırmaya, yerli firmaların inovasyon, girişimcilik, teknoloji vb. konulardan uzak kalmasına ve etkisiz hale gelmesine aynı zamanda ticari faaliyetlerin çevresel standartlar doğrultusunda gelişememesine yol açabilmektedir.

$\mathrm{Bu}$ çalışmada ekonomi sektörünün temel bileşeni olan ticaret politikası ve Dünya Ticaret Örgütü'nün çevre ile ilgili oluşturduğu yeni politikalar ve yapılanmalar literatür tarama yöntemi kullanılarak açıklanmaktadır. DTÖ bünyesinde yapılan sözleşmeler ana hatlarıla incelenerek, çevrenin korunmasıyla ilgili alınan önlemler DTÖ kuruluş görevleri kapsamında irdelenmektedir.

\section{TICARET VE ÇEVRE İLIŞKISI}

Uluslararası ticaret ile çevre arasındaki ilişki, devletlerin, sürdürülebilir kalkınma politikaları 1şığında kurgulamaya çalıştıkları ekonomi ve ekoloji arasındaki dengenin temel öğesi olması açısından önemlidir. Öncelikle ekolojik yönden korunması ve geliştirilmesi gereken değerlere yönelik bilincin, bilimsel ve teknolojik gelişmelere koşut olarak gün geçtikçe artması ve insan odaklı tüketim bilinçsizliğinin, doğal kaynakları yok olma tehlikesiyle karşı karşıya bırakması uluslararası ticaretin çevre öncelikli kararlarla uyumlu gelişmesini gerektirmektedir. Bunun yanı sıra çevreci yatırımların uluslararası ticaretin rekabet potansiyelini etkileyecek olması yeni kaygılar yaratmaktadır. Çevre konusundaki uluslararası çalışmaların ve sözleşmelerin küresel düzeyde etki uyandırması ve geliştirilen koruma politikalarının yerel düzeyde uygulanmasına yönelik gösterilen çabalar, uluslararası ticari faaliyetlerin de bu sürece uygun yenilenmesini ve çevre politikalarıyla uyumlu bir gelişme göstermesini zorunlu kılmıştır (Arda, 1995).

Uluslararası ticarette, çevrenin kirlenmesi ve doğal kaynakların etkin kullanılması yönündeki çabalar, 1971 yılında GATT kapsamında "Çevre ve Ticaretten Sorumlu Çalışma Grubu”nun kurulmasına yön vermiştir. 1987'de "Dünya Çevre ve Kalkınma Komisyonu”nca yayınlanan "Ortak Geleceğimiz Raporu”nda (Türkiye Çevre Koruma Vakfı, 1995): “...Sanayileşmiş ülkelerde korumacılığın artması, ihracatın büyümesini boğmakta ve geleneksel ihraç ürünlerinin çeşitlendirilmesini engellemekte" öngörüsü yer almaktadır. Raporda, UNCTAD bünyesindeki birkaç araştırma projesi dışında, ticaret ile çevre arasındaki ilişkilerin hükümetler arası kuruluşlarca sistematik bir biçimde ele alınmaması eleştirilmektedir. GATT ve UNCTAD'ın görev alanlarına sürdürülebilir kalkınma hedeflerinin eklenmesinin gerekliliği vurgulanmaktadır (İktisadi Kalkınma Vakfı, 1998). GATT içinde kurulan "Çevre ve Ticaretten Sorumlu Çalışma Grubu", 1991 yılından itibaren çevre konusuna ağrlık vermeye başlamıştır. Çevre ve ticaret arasındaki ilişkinin tekrar gündeme gelmesinde ABD ile Meksika arasında gerçekleşen ve "Ton Balığı-Yunus Davası" olarak bilinen 
tartışmalar rol almaktadır (Gül, 2015: 12). Karar gerekçesi: "Farklı çevre politikalarına sahip bir başka üreticinin davranışının, tek taraflı ticaret kısıtlanmaları yoluyla değiştirilmeye çalışılmasının GATT hükümleriyle bağdaşmadığı" yönündedir. Bu karar çevreciler tarafindan tepkiyle karşılanmış ve 1970'li yıllardakinin tersine, serbest ticaretin çevre koruma hedefleri üzerindeki olumsuz etkisi sorgulanmaya başlanmıştır. Uluslararası ticaretin çevre sorunları ve çevre politikaları ile ilişkisi, ticari faaliyetlerin ölçeği ve hızıyla bağlantılı olarak artmaktadır. $\mathrm{Bu}$ süreç, doğal kaynakların korunmasına yönelik ek kaynakların oluşturulmasının yanı sıra eğitim faaliyetlerinin, yönetim stratejilerinin ve yasal düzenlemelerin ticaret ve çevre arasında denge kurabilecek sosyo-ekonomik altyapıyla yapılmasını gerektirmektedir. Özellikle sanayileşemeyen ülkelerde ekonomilerin sorunlu olması, kalkınma planlarında çevreye duyarlılı̆̆ın düşük olmasına, dolayısıyla toplumun çevre bilincinin gelişememesine neden olmaktadır (Meydan Yıldız, 2016). Diğer yandan ticaretteki serbestleşme ile sınır ötesi taşımacılığın ortaya çıkardığı su, hava ve toprak kirliliği sorununun boyutları artmaktadır. Bu süreç, çevreye zarar verecek ürünlerin el değiştirmesine neden olmaktadır. Bunun yanı sıra uluslararası ticaret, çevreye yararlı ürünlerin de dolaşım hızını artırarak, üretim-tüketim yapısını çevre koruma politikalarıyla uyumlu hale getirmektedir (Kaplan, 1991).

Çevre koruma politikaları hem doğal kaynakların akılcı ve verimli kullanımına hem de uluslararası ticaretin çevreyle uyumlu gelişmesine yönelik ilkeler ortaya koymaktadır. Ancak, "uluslararası ticareti denetlemek amaciyla oluşturulan GATT çevre koruma politikalarının ticaret politikalarıyla uyumlu duruma getirilmesine geç başlandığı” görülmektedir (Kaplan, 1991). Bu çerçevede, 1971 yılında GATT bünyesinde oluşturulan, ancak bu süre içerisinde hiçbir etkinlikte bulunmayan çevre ile ilgili çalışma grubu, 1991 yılında çalışmalarına başlayarak bu alanda oluşan anlaşmazlıkların çözümü için bir görüşme platformu görevi üstlenmiştir. Aynı yıl içerisinde OECD bünyesinde de benzer bir gelişme gözlenerek, o güne kadar farklı alanlarda etkinlik gösteren Ticaret ve Çevre Komiteleri "Ticaret ve Çevre Uzmanları Ortak Oturumu" adı altında birleştirilmiştir. Bu girişimleri takiben 1992 yılında gerçekleştirilen Rio Zirvesi sonrasında "Birleşmiş Milletler Ticaret ve Kalkınma Konferansı" (UNCTAD), "Birleşmiş Milletler Çevre Programı" (UNEP) ve "Birleşmiş Milletler Çevre ve Kalkınma Konferansı" (UNCED) bünyelerinde çevre ve ticaretten sorumlu birimler oluşturulmuştur. 1994 yılında DTÖ kapsamında “Ticaret ve Çevre Komitesi” kurulmuştur. 1996 yılında DTÖ’nün Singapur Zirvesi'nde ayrıntılı bir rapor sunan bu komitenin GATT bünyesinde oluşturulan çalışma grubundan temel farkı, görüşme ortamı oluşturmanın ötesinde ticaret ve çevre arasındaki ilişkilere açıklık getirerek sorunlara ilişkin öneriler sunmaktır (İktisadi Kalkınma Vakfi, 1998).

\section{DÜNYA TİCARET ÖRGÜTÜ}

"Gümrük Tarifeleri ve Ticaret Genel Anlaşması", İngilizce "General Agreement on Tariffs and Trade" sözcüklerinin ilk harflerinin GATT olarak 
kısaltılmasıyla oluşmaktadır. II. Dünya Savaşı sonrası 56 ülke hükümeti tarafından Dünya Bankası ve IMF'ye ek olarak üçüncü bir ekonomik yapılanma oluşturulmak istenmiştir. Çok taraflı sözleşme niteliğinde olan GATT, 1947 yılında Cenevre kentinde 23 ülkenin imzasıyla ortaya çıkmıştır. Üye ülkeler "Havana Şartı" olarak adlandırılan anlaşmayı Küba'nın başkentinde imzalamıştır. Ancak maddelerine sadık kalınmaması ve ilkelerinin benimsenememesi nedeniyle Havana Şartı etkisiz, diğer bir deyişle ölü doğmuş bir anlaşma haline gelmiştir. Bretton Woods kurumları, Uruguay Round müzakereleri sonrasında GATT'1n yerine, Dünya Bankası ve IMF'nin yanı sıra üçüncü bir ekonomik öge haline gelecek olan Dünya Ticaret Örgütü'nü kurmuşlardır. 1995 yılından itibaren GATT'ın yerine geçen DTÖ'nün, GATT'dan daha kapsamlı çalışmalar ortaya koyduğu görülmektedir. DTÖ, 2001 yılı itibariyle Doha Kalkınma Gündemi kapsamında, ticaret ile çevre politikaları arasında Çok Taraflı Çevre Sözleşmeleri, sürdürebilir kalkınma, çevre ve piyasa mekanizması gibi konularda, öncelikle gelişmekte olan ülkelerde ihracatın yoğunlaştırılması, yasaklı olan malların ticareti, ambalajlama, markalama, etiket ve dönüşüm konularının uluslararası düzeyde dengede olmasını sağlamak amacıyla gerçekleştirmektedir (Karluk ve Tonus, 2015: 110).

1951 yılında Troquay'da (İngiltere) yapılan görüşmeler sonucunda Türkiye sözleşmeyi imzalayarak 1953 yılında GATT'a katılmıştır. Çevre kirliliğinin 1970'li yıllardan beri dünya gündemini etkilediği göz önünde bulundurulduğunda, GATT'ın 1947 tarihli kuruluş metninde çevrenin açı biçimde yer almaması şaşırtıcı değildir. Kuruluş metninde çevreye dolaylı atıfta bulunan ve günümüzde de çevrenin korunması amaçlı ticaret kısıtlamalarına dayanak oluşturan tek madde "Genel İstisnalar" kısmıdır (İktisadi Kalkınma Vakfı, 1998: 99). II. Dünya Savaşı sonrasında küresel ticarete hız kazandırılması hedefi çerçevesinde kurulan GATT'ın temel amacı, gümrük vergilerinin azaltılması ile miktar kısıtlamalarının kaldırılması yoluyla dünya ticaretinin serbestleşmesinin sağlanmasıdır (Karluk, 1997). Kuruluşundan itibaren GATT, bu temel amaç çerçevesinde ticari bir örgüt vasfina sadık kalarak, bu amaç dışındaki konulardan uzak kalmaya özen göstermiştir. Ancak, zaman içerisinde gümrük vergileri ve miktar kısıtlamalarının kaldırılmasının dünya ticaretinin serbestleşmesi için yeterli olmadığ engeller bulunduğu ortaya çıkmıştır. Bu nedenle GATT, serbest ticareti etkileyen diğer alanlar üzerinde yoğunlaşma gereği duymuştur. Bu alanlardan birisi de çevre politikalarıdır. GATT kurucu metninde çevre konularının yer almamasının nedeni çevre sorunlarının dünya gündemine çok geç girmiş olmasıdır. Temel olarak, serbest ticareti teşvik etmekle görevli olan GATT, çevre koruma ölçünleri koymakla yükümlü değildir.

GATT'ın amaçları, üyelerinin yaşam kalitesini artırmak, reel gelir talebinde istikrarlı büyüme sağlamak ve kaynakların etkin kullanımı ile devletlerarası ticaretin büyümesine destek olmak şeklinde özetlenebilir (Karluk ve Tonus, 2015: 105-106). GATT kapsamında ülkelere ya da üyelere "çevrenin 
korunması gerekçesiyle diğer ülkelerin üretim süreçlerine müdahale izni" tanınmamaktadır (http://content.lms.sabis.sakarya.edu.tr). Uluslararası ticarette farklılık yaratan uygulamaların bir düzene kavuşturulması, ayrımcılığa yol açacak her türlü engelin düzenlenmesi ve bütün ülkelerin ticaret hacmini artıracak seviyede uygulamaların hayata geçirilmesi için ilk olarak "En Çok Kayrılan Ülke" kuralı uygulamaya konmuştur. Böylece, bir ülkeye tanınan kolaylıklar veya verilen tavizler, herhangi bir farklılık gözetmeksizin tüm üye ülkelere tanınmaktadır. Ayrıca "Ulusal İşlem" kuralı altında yurt içinde uygulanan vergi ve işlemlerde yerli-yabancı mal veya hizmet farklılığı gözetmeksizin adil uygulamalarda bulunulmaktadır.

Uruguay Round sonrasında 1994 yılında oluşturulan DTÖ, çevrenin korunması konusunu daha farklı boyutlarda ele almaktadır. Öncelikle DTÖ kuruluş sözleşmesinin giriş bölümünde "çevrenin korunması" ve "sürdürülebilir kalkınmanın sağlanması" ana hedefler olarak belirtilmektedir. Bunun yanı sıra DTÖ ile oluşturulan "Ticarette Teknik Engeller Sözleşmesi", "İnsan, Hayvan ve Bitki Sağlığına İlişkin Önlemler Sözleşmesi” (SPM) ve "Ticaretle İlişkili Fikri Mülkiyet Hakları Sözleşmesi” (TRIPS) çevre ile doğrudan bağlantılı hükümler içermektedir.

Uluslararası ticari faaliyetlerin serbestleştirilmesinin yanı sıra bu sürecin dengeli ve düzenli sürdürülmesini amaçlayan bir sözleşme niteliğindeki GATT, kurumsal nitelik kazanarak 1995'te Dünya Ticaret Örgütü'ne dönüştürülmüştür. Kuruluş sözleşmesi ile DTÖ'nün GATT'ın yerine geçmesi, Uruguay Round sonuçlarını oluşturan bütün metinleri kapsayacak biçimde, kabul edilmiştir (WTO Dispute Settlement, 2018). Uruguay Round'un uluslararas1 ticari faaliyetlerin gelişim hacmine yönelik temel yararı, anlaşmazlıkların çözümüne ilişkin görüş birliğine varılması ile üye ülkeler arasında DTÖ kapsamındaki uyuşmazlıkların çözümüne yönelik sistemin güçlendirilmesi ve DTÖ bünyesindeki anlaşmazlıkların çözümü için ilgili birimin oluşturulması olmuştur (WTO Dispute Settlement, 2018; Karluk, 2014). DTÖ'de alınan kararlar tam katılımın üye ülkelerce sağlanması durumunda, en az iki yılda bir toplanan Bakanlar Konferansı'nda ya da Cenevre'de resmi temsilcilerce oydaşma yöntemiyle alınmaktadır (WTO Legal Texts, 2018). Bu bağlamda DTÖ'nün, Uluslararası Para Fonu (IMF) ve Dünya Bankası ile benzerlik göstermediği görülmektedir. "DTÖ'de yönetsel kararları alma yetkisi herhangi bir yönetim kuruluna devredilmediği gibi, kuruluşun idari ya da bürokratik organları da üye ülkelerin bireysel politikaları üzerinde etki sahibi değildir". Üye ülkelere yönelik yaptırımlar, ilgili kurallara itaatsizlik ve keyfilik durumunda DTÖ tarafından değil, üye ülkelerce gerçekleştirilmektedir (WTO Legal Texts, 2018; WTO Dispute Settlement, 2018).

2017 yılı itibariyle toplam 160 üyesi bulunan bir uluslararası örgüt içinde "oydaşma" yöntemi temel alınarak bir karara varılması zor görünse de, bu yöntemin üye ülkelerce daha kabul edilebilir bir durumda olması farklı bir avantaj sunmaktadır. Bu güçlüğe nazaran DTÖ çatısı altında, ticari yapıda kabul gören 
birçok sözleşmenin sonuçlandırıldığı görülmektedir. DTÖ'de kararlar, tüm üye ülkeleri kapsayan çeşitli düzeylerdeki konsey ve komiteler vasıtasıyla alınmaktadır. Örgütün en yüksek karar alma organı ise Bakanlar Konferansı'dır. Konferans her iki yılda bir toplanmaktadır (Ministry of Economy, 2018). Üye ülkeler temsilcilerinden oluşan Genel Konsey, DTÖ’nün Bakanlar Konferansları arasında kalan dönemlerde yapılan olağan ve günlük çalışmalarını yürütmektedir. DTÖ kuruluş anlaşmasında, Genel Konsey'in, Anlaşmazlıkların Çözümü Organı ve Ticaret Politikalarını Gözden Geçirme Organı olarak bir araya gelebileceği ifade edilmektedir (bkz. Şema 1).

Şema 1. DTÖ Organizasyon Şeması

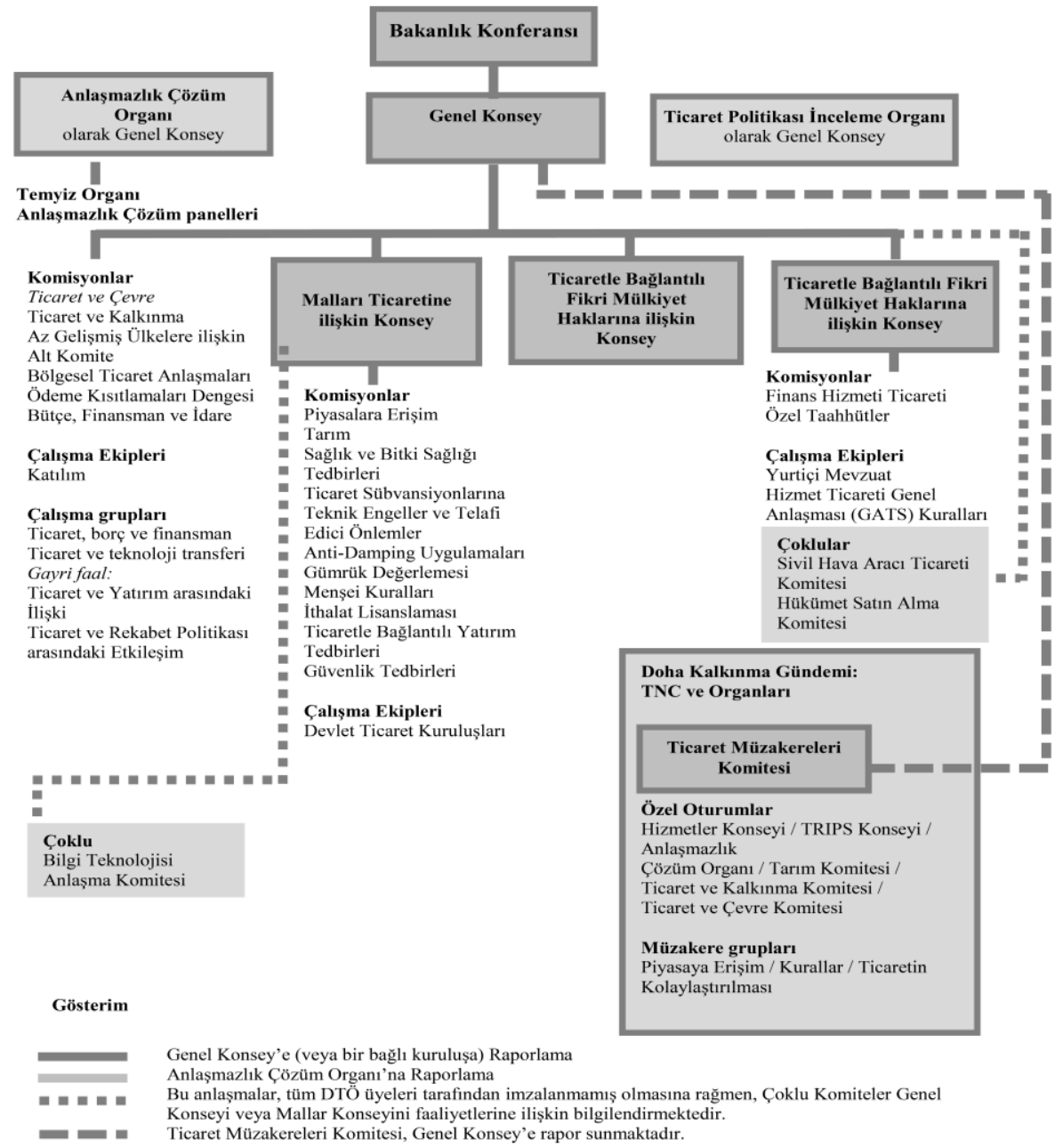

Genel Konsey, Ticaret Politikası İnceleme Organı ve Anlașmazlık Çözüm Organını da karṣılamaktadır.

Kaynak: WTO, "Understanding the WTO" http://www.wto.org/english/thewto_e/whatis_e/tif_e/tif_e.htm. 
Bakanlar Konferansı'na karşı sorumlu olan bu üç farklı birim, farklı işlevlerin yapıldığı ve DTÖ üyelerinin temsil edildiği faktörlerdir (Karluk, 1993; Karluk, 2014). DTÖ'nün amacı, "üye ülkelerin ticaret ve ekonomi alanındaki ilişkilerini geliştirmek, yaşam ölçünlerini yükseltmek, tam istihdamı gerçekleştirmek, reel gelir ile gerçek talep hacmindeki istikrarlı artışı sağlamak, mal ve hizmet üretim ve ticaretini geliştirmek, aynı zamanda da dünya kaynaklarının sürdürülebilir kalkınma hedefine en uygun bir şekilde kullanımına olanak vermek ve gerek çevreyi korumak, gerekse farklı ekonomik düzeydeki ülkelerin gereksinmelerine ve endişelerine cevap verecek şekilde mevcut kaynaklarını geliştirmek olarak belirlenmiştir” (Yenipazarlı, 2003: 4).

\section{A. DTÖ'nün Çevre Sorunlarına Yaklaşımı}

Ticari bir örgüt olan GATT ve onun tamamlayıcısı olan DTÖ, çevre ile ilgili alanlarda giderek daha fazla faaliyet göstermekte ve GATT çerçevesinde çözümü öngörülen anlaşmazlıklar ağırlıklı olarak çevre sorunları ile ilgili bir boyut taşımaktadır. Tüm bu nedenlerden dolayı serbest ticaret taraftarları, GATT'a "yeşil”" çıkarların giderek daha fazla etkisi altında kaldığ 1 eleştirisini yöneltmektedir. Ancak çevre ve ticaret kapsamında üzerinde halen fikir birliğine varılamayan birçok alan bulunmaktadır. Çok Taraflı Çevre Anlaşmaları'ndan kaynaklanan ticari kısıtlamalar, çevre politikalarında giderek daha sık kullanılan ekonomik araçların serbest ticaret üzerindeki etkileri, üretim ölçünlerinin ticari boyutu gibi sorunlar bu tartışmalar arasında yer almaktadır. Çevrenin korunması bağlamında sanayi kirliliği ve bu konuda gelişen ticari ilkeler, kurumsal anlamda ilk kez 1971 yılında kurulan "Çevre Önlemleri ve Uluslararası Ticaret Çalışma Grubu" ile gündeme gelmesine karşın, bu çalışma grubu, çevresel paketleme ve etiketleme ile ticari sonuçlar doğurabilecek çevre düzenlemelerini 1991-1994 döneminde gündeme getirmiştir. Marakeş’teki toplantılarda çok taraflı ticaret rejiminin yetkilerini aşmadan, ticaret ve çevreye ilişkin çok taraflı rejimin korunması ve sürdürülebilir kalkınmanın desteklenmesi belirtilmiştir (IISD ve UNEP, 2000: 25).

Giderek artan çevresel sorunlara karşı duyarlılık, DTÖ’nün çevre konularına değinmesine sebep olsa da bu oldukça yeni bir yaklaşımdır. 1994'te Uruguay'da toplanan ticaret bakanları, ticari ve çevresel konular üzerinde ayrıntılı ve geniş kapsamlı bir programın yapılmasına karar vermişlerdir. Aynı yıl ilk defa "Dünya Ticaret ve Çevre Komitesi" kurulmuştur. Böylece ilk defa dünya ticaret örgütünün içeriğine çevresel konular da resmi olarak alınmıştır. DTÖ kapsamında ortaya konulan ilgili yaptırımlar, çevre ve ticaret açısından uluslararası alanda en çok tartışılan sorunlar arasındadır. Çevre bilincine paralel olarak yüksek çevre ölçünlerini belirleyen gelişmiş ülkelerdeki üreticiler, bu ölçünlere uymak için oldukça masraflı üretim yatırımları yapmak durumunda kalmaktadırlar (İktisadi Kalkınma Vakfı, 1998: 105-106). Böylece, maliyetler artırmaktadır. Ancak, çevre ölçünleri düşük olan ülkeler, çevre koruma kaygısı taşımadan ya da herhangi bir yatırım yapma zorunluluğu olmadan aynı ürünleri çok daha ucuza mal 
edebilmektedir. GATT/DTÖ çerçevesinde yasal temeli olmamasına karşın "çevre dampingi" ticarette teknik engel olarak kullanılabilmektedir (İktisadi Kalkınma Vakf1, 1998: 105-106). İlaveten ticaretin tarafları serbest ticareti engelleyebilecek, bilimsel verilerle desteklenmeyen, çevre koruma gerekçeli herhangi bir teknik engeli de kabul etmemektedir.

"Ticarette Teknik Engeller Anlaşması" (TBT) ile başlangıçta dünya çapında serbest ticaretin karşısındaki en önemli engel olarak görülen tarifelerin GATT kapsamında gerçekleştirilen görüşmeler sonucunda azaltılması, önemli bir başarı olarak değerlendirilmektedir. Ancak zaman içerisinde ülkeler, iç pazarlarını korumak amaciyla tarifelerin yerini alabilecek farklı önlemler belirlemeye de başlamışlardır. $\mathrm{Bu}$ önlemler arasında teknik engellerin giderek ağırlık kazandığ 1 ve dünya ticaretini olumsuz yönde etkilediği düşünülmektedir. Teknik engeller, genel olarak ülkelerin kalite, sağlık ve çevre gibi alanlarda belirledikleri ölçünler ve bu ölçünlerin kontrolü için geliştirdikleri yöntemlerden oluşmaktadır. Uluslararası ticaret için bir engel oluşturan bu ölçünler, ürüne yönelik olabileceği gibi (biçim, etiket, ambalaj vb.), üretim sürecinde kullanılan maddelere yönelik de olabilir (üretim sırasında kullanılan teknolojiler, üretim koşulları vb.) (Karluk, 2014). Ticarette Teknik Engeller Anlaşması, daha yüksek çevre ölçünleri belirleyerek uluslararası ölçünlerden sapma olanağını da açıkça sunmaktadır. Ancak bu açıdan özellikle vurgulanan unsur, ölçünlere ilişkin uygulamalarda yerli ve yabancı ürünlerin aynı kurallara tabi tutulmasıdır. Özetle, yabancı ürünleri hedef almadıkları sürece ölçünler teknik engel olarak kabul edilmemektedir. $\mathrm{Bu}$ şekilde serbest ticaretin gereksiz engeller nedeniyle zarar görmemesi hedeflenmektedir. Anlaşmanın GATT çerçevesinde oluşturulan uygulamalardan temel farkı, yalnızca ürün ölçünlerini değil, bir ölçüde izin vermek suretiyle üretim yöntemlerine ilişkin ölçünleri de yasallaştırmasıdır. DTÖ, ürünün son şekli üzerinde etkili olduğu ölçüde üretim sürecini de göz önünde bulundurmaktadır. $\mathrm{Bu}$ kapsamda üretim süreci sırasında kullanılan ve ürünün son biçimini insan sağllğı ile çevreye zarar verecek şekilde değiştiren bazı işlemlere yönelik ölçünler teknik engel sayılmamaktadır.

"İnsan, Hayvan ve Bitki Sağlığına İlişkin Önlemler Sözleşmesi” (SPM), yabani hayvan ve bitki dokusu da dahil olmak üzere hayvan ve bitki sağlığına yönelik olması nedeniyle çevre ile doğrudan ilişkilidir. "Anlaşma kapsamında ülkeler, yerli ve yabancı ürünler arasında ayrım gözetmemek kaydıyla insan, hayvan ve bitki sağlı̆̆ına zarar verdiği gerekçesiyle ticareti kısıtlayıcı önlemler alabilirler. Ancak bu kapsamda alınacak tüm önlemlerin bilimsel ilkeler ve kanıtlara dayalı olması koşulu bulunmaktadır" (TÇV, 1988).

"Ticaretle İlişkili Fikri Mülkiyet Hakları Sözleşmesi” (TRIPS)'nde, üretim süreci ve ticarete ilişkin "fikri mülkiyet hakları" yer almaktadır. Üretim sürecinde çevre dostu teknoloji kullanımının giderek özendirildiği günümüzde, söz konusu teknolojilerin "fikri mülkiyet hakkı" konusu da giderek daha sık gündeme gelmektedir. TRIPS çerçevesinde yer alan konular arasında çevre açısından en fazla tartışmaya yol açan madde, Anlaşma'nın patent verilebilir 
buluşlara sinırlama getiren hükmüdür. $\mathrm{Bu}$ madde çerçevesinde bir ülkenin biyolojik çeşitliliği kapsamında yer alan herhangi bir madde patent verilebilir buluşlar dışında tutulabilmektedir. Ancak söz konusu ülkenin bu maddenin korunması için gerekli koşulları sağlayamaması halinde bu hüküm geçerli değildir. Dünyanın biyolojik kaynaklarının önemli bölümünün gelişmekte olan ülkelerin sınırları içerisinde yer aldığı, ancak bu ilkelerin söz konusu kaynakları korumak için gerekli donanıma nadiren sahip olduğu göz önünde bulundurulduğunda, bu maddenin Kuzey ve Güney çatışmasında yeni bir sorun oluşturacağını söylemek olasıdır.

Çevrenin korunması amaciyla uygulanan, ancak ticareti doğrudan ya da dolaylı biçimde etkileyen tüm tedbirler, "Ticaretle Bağlantılı Önlemler" (TradeRelated Environment Measures-TREMs) olarak tanımlanmaktadır (WTO, 2018). Herhangi bir sözleşme tarafı, sözleşmenin kendisine sağladığı bir çıkarın kaybolması veya sözleşmenin amaçlarından birine uyulmaması halinde taraflardan görüşme talebinde bulunabilmektedir. $\mathrm{Bu}$ görüşmelerden olumlu bir sonuç çıkmaması durumunda GATT üyelerine başvurulmaktadır.

"Ticaret Politikalarını Gözden Geçirme Mekanizması" ile bağlı olarak çalışan "Ticaret Politikalarını Gözden Geçirme Organı"nın hedefi, çok taraflı ticaret sistemlerini, üye olan ülkelerin sahip oldukları ticari yapıların, uygulamaların ve kararların nasıl etkilediğini incelemektir. Dünya Ticaret Örgütü, devletler arasında anlaşmazlıkların oluşması durumunda, ilgili sorunların en kısa sürede çözülerek tekrar yaşanmaması konusunda çözümler üretmektedir. İlgili kurallar GATT uygulamalarında farklılaşmaktadır. Arabuluculuk ve taraflar arası uzlaştırma esasıyla geliştirilen kurallar ayrıntılı olarak incelenmekte ve açıklık, şeffaflık ve nesnellik ilkesiyle yürütülmektedir (Yılmaz, 2018).

\section{Investment)}

B. Çok Taraflı Yatırım Anlaşması (Multilateral Agreement on

"Çok Taraflı Yatırım Anlaşması", "ulusötesi sermayenin anayasası" şeklinde tanımlanabilecek, gizli olarak 1995 yılından beri yürütülen ve içinde Türkiye'nin de yer aldığı “Ekonomik İşbirliği ve Kalkınma Örgütü”ne (OECD) üye olan yirmi dokuz ülkeyi içeren anlaşmadır. OECD bünyesinde sürdürülmekte olan görüşmelerin en geç 1999 Kasım ayında sonuçlandırılması ve son haliyle tasarının imzalanması planlanmışken, bir takım görüş ayrılıklarının yanı sıra Fransa ve İngiltere hükümetlerinin görüşmelerden çekilme kararı, MAI'ya ilişkin yeni gelişmeleri gündeme getirmiştir. MAI'nın içeriğine karşı bir gerekçe sunmayıp, görüşmelerin Dünya Ticaret Örgütü'ne taşınması görüşü, Fransa ve İngiltere'nin OECD içindeki MAI görüşmelerinden çekilme gerekçelerini oluşturmuştur. MAI görüşmeleriyle koşut olarak, MAI'nın özünü aynen taşıyan, bölgesel-alt anlaşma ve örgütlenme çalışmaları da sürdürülmektedir. $\mathrm{Bu}$ çalışmalar gerek MAI görüşmelerinin uzamasını, gerekse MAI'nın Dünya Ticaret Örgütü içine atılarak, sulandırılmasını önlemekte, ulusötesi sermayenin yönelimi önüne bir engel çıkmaması, oluşturulan uluslararası organizasyonla garantilenmekte ve MAI'nın tüm altyapısının oluşturulması yönünde 
işlevlendirilmektedir (www.antimai.org.tr). Ulusötesi sermayenin "küresel anayasası" olarak adlandırılan MAI, birden bire ortaya çıkan bir olgu değildir. Küresel yayılmanın araç, yöntem ve işleyişini oluşturmaya yönelik çalışmaların geçmişi, 1944'lere, yani Bretton Woods'la birlikte başlayan uluslararası ticaretin serbestleşmesinin kurumsal düzenlemeleri sürecine kadar uzanmaktadır. MAI taslağı NAFTA ve AT anlaşmaları örnek alınarak oluşturulmuştur (Demirer, vd., 2000). MAI bu kapsamiyla, ulusötesi sermayenin girdiği her ülkede, üretimden pazarlamaya, dilediği alanda ve istediği kadar mülkiyet edinmekten, kârlarını ve yatırımlarını hiçbir kısıtlamaya tabi olmadan dilediği ülkeye aktarabilmeye kadar, hiçbir denetim ve sınırlamayla karşılaşmadan hareket etmesini sağlayan yasal bir düzenlemedir

\section{TÜRKIYY'DE DTÖ VE ÇEVRE İLISSKISİ}

Ülkelerin ekonomik kalkınmasında ve gelişmesinde dış ticaretin önemi her geçen gün artmaktadır. Uluslararası ticaretin kurallarının belirlenmesi de bu anlamda önem taşımaktadır. Dünya Ticaret Örgütü, çok taraflı ticaret sisteminin uluslararası boyuttaki yasal ve kurumsal temeli olarak kabul edilen yapısıyla, 1 Ocak 1995'te resmen faaliyete geçmiştir. Türkiye 26 Mart 1995 tarihinden beri DTÖ’de kurucu üye olarak yer almaktadır (Dış İşleri Bakanlığı, 2018). Kurucu üye olarak Türkiye, DTÖ'nün ticarete ilişkin kurallarına da uymayı taahhüt etmektedir. Anlaşma metninde:

“...ticaret ve ekonomik girişim alanındaki ilişkilerinin, hayat standardını yükseltmek, tam istihdamı ve istikrarlı bir şekilde artan reel gelir ve gerçek talep hacmini sağlamak, mal ve hizmet üretimini ve ticaretini geliştirmek, aynı zamanda da dünya kaynaklarının sürdürülebilir kalkınma hedefine en uygun bir şekilde kullanımına olanak vermek ve gerek çevreyi korumak, gerek farklı ekonomik düzeydeki ülkelerin ihtiyaç ve endişelerine cevap verecek şekilde mevcut kaynaklarını geliştirmek amaçlarına hizmet etmesi gerektiğini, ayrıca, gelişme yolundaki ülkelerin ve bunların arasında yer alan en az gelişmiş olanların artan dünya ticaretinde ekonomik kalkınma ihtiyaçları ile orantılı bir pay elde etmelerini sağlamak amacıyla gayret harcanmasına ihtiyaç olduğunu, karşılıklı menfaat esasına dayalı ve gümrük tarifelerinde ve ticaretin karşılaştığı diğer engellerde önemli indirimler sağlayan ve uluslararası ticaret ilişkilerinde ayırımcı muameleyi ortadan kaldıran anlaşmalar akdetmek yoluyla bu amaçlara ulaşılmasına katkıda bulunmayı arzu ederek, Gümrük Tarifeleri ve Ticaret Genel Anlaşması'nı, geçmişte ticaret serbestleştirilmesinde elde edilen neticeleri ve Uruguay Round Çok Taraflı Ticaret Müzakerelerinin sonuçlarını içeren bütünleştirilmiş, uygulanabilir ve kalıcı birçok taraflı ticaret sistemi geliştirme..."

amaçlandığı belirtilmektedir (RG: 29.1.1995/22186). Ayrıca 1. Doha Deklarasyonu'nun 31. maddesinde (iii) "çevresel mal ve hizmetlere tarife ve tarife dış1 engellerin azaltılması veya uygun şekilde giderilmesi” öngörülmektedir. 31 . madde içeriğinde, "daha az maliyet için hükümetleri destekleyen teknolojilere ve ürünlere daha fazla erişimin" çevre ve kalkınma hedeflerine (sağlık, kirlilik önleme, yenilenebilir enerji kaynaklarının kullanılması gibi) ulaşmasını sağlayacak bir "kazan-kazan" sonucunun oluşmasına olanak vereceğinin yer alması ticaret ve çevre ilişkileri açısından önemlidir.

Türkiye'de yatırım ortamının iyileştirilmesi çalışmaları hem ulusal hem de uluslararası yatırımların artırılması açısından büyük önem taşımaktadır. 2001 yılında Bakanlar Kurulu Prensip Kararı ile kabul edilen "Türkiye'de Yatırım 
Ortamının İyileştirilmesi Reform Programı" çerçevesinde, Yatırım Ortamını İyileştirme Koordinasyon Kurulu (YOİKK) kurulmuştur. YOİKK, 2001 yılından bu yana yatırımın her aşamasında gerek yerli gerekse uluslararası yatırımcıların karşılaştıkları idari ve teknik engelleri önlemek ve yatırım ortamının rekabet gücünü artırmak üzere çalışmalarını sürdürmektedir. YOİKK bünyesinde teknik düzeydeki çalışmalar, özellikle sivil toplum kuruluşlarının görüşleri doğrultusunda, yatırım ortamını doğrudan ilgilendiren konulardan oluşan 10 teknik komite aracılığıyla yürütülmektedir. Bunlar: "Şirket İşlemleri ve Kurumsal Yönetim Teknik Komitesi", "İstihdam Teknik Komitesi”, "GITTES ve Sektörel Lisanslar Teknik Komitesi", "Vergi ve Teşvikler Teknik Komitesi”, "Dış ticaret ve Gümrükler Teknik Komitesi”, "Fikri, Sınai Mülkiyet Hakları ve Ar-Ge Teknik Komitesi", "Yatırım Ortamı Mevzuatı ve Hukuksal Süreçler Teknik Komitesi", "Finansmana Erişim Teknik Komitesi” ve "Altyapı Teknik Komitesi” ve "Yatırım Yeri, Çevre ve İmar İzinleri Teknik Komitesi" dir. Bütün bu yatırım araçlarının işlemlerinden önce, başvuru aşamasında "Çevresel Etki Değerlendirmesi" uygulamaları gerekli olup ÇED raporunun bulunması temel ilkeler arasında yer almaktadır (Ekonomi Bakanlığı, 2017). ÇED raporlarının sonuçları irdelendiğinde, ÇED Olumlu Raporu'nun yıllar içerisinde sayısal olarak arttığı gözlenmektedir (Çevre ve Şehircilik Bakanlığı, 2018). Bu durumu uluslararası yatırımların çevresel sorun yaratmayacakları beklentisi olarak okuyabileceğimiz gibi, uluslararası yatırımcılara çevresel engeller çıkarılmamasının bir yolu olarak da bakabiliriz.

Türkiye Cumhuriyeti Merkez Bankası tarafindan IMF Altıncı El Kitabı'na göre de, Türkiye'ye gelen uluslararası doğrudan yatırımlar 2016 yılında 12 milyar ABD Doları olarak açıklanmıştır. Türkiye, dünyada 2016 yılında en fazla Uluslararası Doğrudan Yatırım (UDY) çeken ülkeler arasında 24. ülke (bkz. Tablo 1), gelişen ülkeler arasında ise 12. ülke olarak yer almaktadır.

Tablo 1: En Fazla UDY Çeken On Ülke ve Türkiye 2014-2016 (Milyar ABD Dolar1)

\begin{tabular}{|r|l|r|}
\hline \multicolumn{3}{|c|}{2014} \\
Sira & Ülke & UDY \\
\hline 1 & ABD & 171,6 \\
\hline 2 & Cin & 128,5 \\
\hline 3 & Hong Kong & 113,0 \\
\hline 4 & Singapur & 74,0 \\
\hline 5 & Brezilya & 73,1 \\
\hline 6 & Kanada & 59,1 \\
\hline 7 & Hollanda & 53,3 \\
\hline 8 & Ingiltere & 44,8 \\
\hline 9 & Avustralya & 40,3 \\
\hline 10 & Irlanda & 37,4 \\
\hline 22 & Türkiye & 12,5 \\
\hline & Dünya & \\
& Toplamı & $1.323,9$ \\
\hline
\end{tabular}

\begin{tabular}{|r|l|r|}
\hline \multicolumn{3}{|c|}{2015} \\
Sira & Ülke & UDY \\
\hline 1 & ABD & 348,4 \\
\hline 2 & İrlanda & 188,3 \\
\hline 3 & Hong Kong & 174,4 \\
\hline 4 & Cin & 135,6 \\
\hline 5 & Singapur & 70,6 \\
\hline 6 & İsviçre & 70,4 \\
\hline 7 & Hollanda & 68,8 \\
\hline 8 & Brezilya & 64,3 \\
\hline 9 & Fransa & 47,0 \\
\hline 10 & Hindistan & 44,1 \\
\hline 18 & Türkiye & 17,3 \\
\hline & Dünya & \\
& Toplamı & $1.774,0$ \\
\hline
\end{tabular}

\begin{tabular}{|r|l|r|}
\hline \multicolumn{3}{|c|}{2016} \\
Sira & Ülke & UDY \\
\hline 1 & ABD & 391,1 \\
\hline 2 & İngiltere & 253,8 \\
\hline 3 & Cin & 133,7 \\
\hline 4 & Hong Kong & 108,1 \\
\hline 5 & Hollanda & 92,0 \\
\hline 6 & Singapur & 61,6 \\
\hline 7 & Brezilya & 58,7 \\
\hline 8 & Avustralya & 48,2 \\
\hline 9 & Hindistan & 44,5 \\
\hline 10 & Rusya Fed. & 37,7 \\
\hline 24 & Türkiye & 12,0 \\
\hline & Dünya & \\
& Toplamı & $1.746,4$ \\
\hline
\end{tabular}

Kaynak: WIR, 2017, UNCTAD 
Türkiye'de yıllara göre dış ticaret değişimleri incelendiğinde dış ticaret dengesinin negatif değerde arttı̆g 1 (dış ticaret açı̆̆ının arttığ $)$, ithalat ve ihracat toplamını ifade eden diş ticaret hacminin ise yıllara oranla pozitif değerde arttığ 1 görülmektedir (bkz. Tablo 2).

Tablo 2: Y1llara Göre Diş Ticaret Değişimimi (1923-2016)

\begin{tabular}{|l|l|l|l|l|l|}
\hline Yıl & $\begin{array}{l}\text { İhracat } \\
\text { Değer }\end{array}$ & $\begin{array}{l}\text { İthalat } \\
\text { Değer }\end{array}$ & $\begin{array}{l}\text { Dıș Ticaret } \\
\text { Dengesi } \\
\text { Değer }\end{array}$ & $\begin{array}{l}\text { Diș Ticaret } \\
\text { Hacmi } \\
\text { Değer }\end{array}$ & $\begin{array}{l}\text { İhracatın } \\
\text { İthalatı } \\
\text { Karşılama } \\
\text { Oranı \% }\end{array}$ \\
\hline 1923 & 50790 & 86872 & -36082 & 137662 & 58,5 \\
\hline 1928 & 88278 & 113710 & -25432 & 201988 & 77,6 \\
\hline 1933 & 58065 & 45091 & 12974 & 103156 & 128,8 \\
\hline 1938 & 115019 & 118899 & -3880 & 233918 & 96,7 \\
\hline 1943 & 196734 & 155340 & 41394 & 352074 & 126,6 \\
\hline 1948 & 196799 & 275053 & -78254 & 471852 & 71,5 \\
\hline 1953 & 396061 & 532533 & -136472 & 928594 & 74,4 \\
\hline 1958 & 247271 & 315098 & -67827 & 562369 & 78,5 \\
\hline 1963 & 368087 & 687616 & -319529 & 1055703 & 53,5 \\
\hline 1968 & 496419 & 763659 & -267240 & 1260078 & 65 \\
\hline 1973 & 1317083 & 2086216 & -769133 & 3403299 & 63,1 \\
\hline 1978 & 2288163 & 4599025 & -2310862 & 6887187 & 49,8 \\
\hline 1983 & 5727834 & 9235002 & -3507168 & 14962836 & 62 \\
\hline 1988 & 11662024 & 14335398 & -2673374 & 25997422 & 81,4 \\
\hline 1993 & 15345067 & 29428370 & -14083303 & 44773436 & 52,1 \\
\hline 1998 & 26973952 & 45921392 & -18947440 & 72895344 & 58,7 \\
\hline 2003 & 47252836 & 69339692 & -22086856 & 116592528 & 68,1 \\
\hline 2008 & 132027196 & 201963574 & -69936378 & 333990770 & 65,4 \\
\hline 2013 & 151802637 & 251661250 & -99858613 & 403463887 & 60,3 \\
\hline 2014 & 157610158 & 242177117 & -84566959 & 399787275 & 65,1 \\
\hline 2015 & 143838871 & 207234359 & -63395487 & 351073230 & 69,4 \\
\hline 2016 & 142529584 & 198618235 & -56088651 & 341147819 & 71,8 \\
\hline & & & & & \\
\hline
\end{tabular}

$$
\text { *(Değer: Bin ABD \$) }
$$

Kaynak: TÜİK, 2018, İstatistiki Tablolar, http://www.tuik.gov.tr/PreTablo.do?alt_id=1046

TÜIKK tarafindan yapılan Girişimlerin Çevresel Harcama ve Gelirleri (2007-2016) durumu incelendiğinde (bkz. Tablo 3) üretim süreçleri ile mal ve hizmetlerin tüketiminden kaynaklanan çevre kirliliğinin önlenmesi, azaltılması ve giderilmesi amaçlı faaliyetler için yapılan harcamaların yıllara göre arttığ görülmektedir. Çevresel gelirler atık, hurda ve çevresel yan ürünlerden elde edilen gelirlerle, girişimin diğer girişimlere, belediyelere vb. yerlere verdiği çevresel hizmetlerden elde ettiği geliri de kapsamaktadır. Bu harcamaların da yıllara oranla arttı̆̆ gözlenmektedir. 
Tablo 3: Girişimlerin Çevresel Harcama ve Gelirleri (2007-2016)

\begin{tabular}{|c|c|c|c|c|}
\hline \multirow{2}{*}{ Yll } & \multicolumn{3}{|c|}{ Çevresel harcamalar } & \multirow{2}{*}{$\begin{array}{c}\text { Toplam } \\
\text { çevresel gelir } \\
\text { (TL) }\end{array}$} \\
\hline & Toplam & Cari harcamalar & $\begin{array}{l}\text { Yatırım } \\
\text { harcamaları }\end{array}$ & \\
\hline 2007 & 782878508 & 535582299 & 247296208 & 519028107 \\
\hline 2008 & 871668976 & 609503856 & 262165120 & 1933876716 \\
\hline 2009 & 1498427806 & 1344865441 & 153562364 & 2051014995 \\
\hline 2010 & 1833790497 & 1661528896 & 172261601 & 3044676611 \\
\hline 2012 & 3527204871 & 2766483820 & 760721051 & 4059159056 \\
\hline 2013 & 4066703368 & 3710304489 & 356398879 & 5517966908 \\
\hline 2014 & 4431107552 & 3980868469 & 450239083 & 7189271651 \\
\hline 2015 & 5309534579 & 4536521630 & 773012949 & 8413873724 \\
\hline 2016 & 7123242246 & 6018877373 & 1104364873 & 9891689700 \\
\hline
\end{tabular}

Kaynak: TÜİK, 2018, İstatistiki Tablolar, http://www.tuik.gov.tr/PreTablo.do?alt_id=1046.

\section{SONUÇ VE DEĞERLENDİRME}

Dünya ekonomisinin son otuz yılda yaşadığı değişim süreci bütün toplumsal yapıları derinden etkilediği gibi toplumsal tarafları da etkilemektedir. Genellikle küreselleşme tartışmalarının ana noktasını oluşturan ve sermayenin küreselleşmesi olarak aktarılan finansal piyasalarda, uluslararası ticarette ve yabancı yatırımlardaki hızlı yükseliş artık küçük bir köy olarak nitelendirilen küreselleşmiş bir dünyanın oluştuğu savlarına dayanak oluşturmaktadır.

Son zamanlarda uluslararası ticaret alanında tartışılan konu, yerel düzeyde oluşturulan ulusal çevre politikalarının, küresel düzeyde dünya ticaretini nasıl etkileyeceğidir. Diğer tarafta, serbest ticari faaliyetlerin çevrenin korunmasına yönelik ortaya konulan stratejilerle uyumlu gelişememesi yönünde tedirginlikler söz konusudur. Bir yanda "dünya ticaretinin serbestleşmesi alanında uzun ve zorlu bir süreç sonunda ulaşılan bu noktanın, çevrenin korunması adı altında oluşturulacak korumacı politikalarla" (TÇV, 1995) engellenebileceğine yönelik tedirginlikler varken, diğer tarafta "ticari alanda maksimum kâr elde etmek için çevrenin feda edileceği kuşkusu” (TÇV, 1995) hakimdir. Kısacası, çevre ve ticaret arasında bir denge oluşturulması zorunludur. Aksi takdirde, çevresel konuların ihmal edilmesi ekosistemleri ve biyosferin geleceğini tehlikeye sokmaktadır. Kısa vadeli kâr elde etme hırsının ve düşüncesinin çevresel değerlerde geri dönüşü zor ve hatta imkansız bir şekilde zarar oluşturabileceği unutulmamalıdır.

1987 yılında başlayan GATT/DTÖ görüşmeleri doğrultusunda, zengin sanayileşmiş ülkelerin ve çok uluslu şirketlerin kendi çıkarlarını ve sermayelerini diğer ülkelere uyarlama çabası son zamanlarda gündemi oluşturmaktadır. Gerek Dünya Ticaret Örgütü'nün dünya ticareti üzerinde çok uluslu sermayenin ortak kurallarını belirleme misyonu gerekse MAI ile sermayenin önündeki her türlü engelin kaldırılması uğraşları, çevre konusunda bugüne kadar gösterilen, ulusal ve 
uluslararası çabaları anlamsız hale getirmektedir. Özellikle, gelişmekte olan ülkelerin iç hukukunu bu uluslararası düzenlemelere uydurma zorunluluğu ve karar alma süreçlerindeki cılız duruşları, geleceğin çevre sorunları olarak ortaya çıkacaktır. Ulusal hukuk düzenlemeleri içindeki kültür ve çevre değerlerini kamu ve ülke yararına korumayı öngören yasal önlemleri de yine devre dışına çıkararak yeni bir dünya düzeninin kurulması ekseninde çabalar sürmektedir.

Uluslararası ticaret ilişkileri, ulusal kalkınmanın en önemli aktörleri arasında yer almaktadır. Ancak, ticaret, çevre ve kalkınma stratejileriyle birlikte değerlendirilerek katılımc1, dengeli ve eşitlikçi yapıya sahip bir sürdürülebilir kalkınmanın sağlanması gerekir (Sutherland vd., 2004; İriç, 2014). Böylece, tarım, sanayi, hizmetler, inşaat ve turizm sektörü içinde oluşturulacak alt sektörler arasındaki dengenin, bölgesel rekabet edebilirlikte kullanılması ve ulusötesi pazarlanması sağlanarak ulusal kalkınma hedefleriyle uyumlu yerel ekonomik politikaların yaşama aktarılması önemlidir.

Günümüzde çevre sorunları sadece teknik bir sorun olmaktan çıkmıştır. Uluslararası çalışmalar ve sözleşmeler çerçevesinde gelişen çevreci politikaların yasal düzenlemelerde yer alması ise tek başına yeterli değildir. DTÖ’nün ticarette teknik engellerin kaldırılmasına yönelik politikaları, ticari faaliyetlerin ve yatırımların çevresel etkilerinin de dikkate alınmasını gerektirmektedir. Dengeli ve sürekli bir ekonomik kalkınmanın sağlanması, iç ve dış pazarda rekabet edebilecek "yeşil sanayi-yeşil istihdam" politikasının oluşturulmasına ve yerel kaynakların etkin kullanımına dayalı hedefler belirleyen ulusal ticaret politikasına da bağlıdır.

\section{KAYNAKÇA}

Arda, M. (1995). "Uluslararası Ticaret Çevre İlişkileri”, Yeni Türkiye Dergisi, Çevre Özel Sayısı, Ankara.

Çevre ve Şehircilik Bakanlığı, (2018). http://www.csb.gov.tr/gm/ced/index.php?Sayfa=sayfaicerikhtml\&IcId=673\&detId=674\&us tId $=673,(14.03 .2018)$.

Demirer, G.N., Demirer, T., Uğurlu, Ö. (2000). "Emperyalizmin 21. Yüzyıl Stratejisi MAI'nin Çevresel Boyutu, Küreselleşmenin Ekolojik Sonuçları”, Özgür Üniversite Kitaplığı: 28, Ankara: Türkiye ve Ortadoğu Forumu Vakfi.

Dış İşleri Bakanlığı, 2018, mfa.gov.tr, (10.03.2018).

Dünya Çevre ve Kalkınma Komisyonu, (1991). Ortak Geleceğimiz Raporu, Türkiye Çevre Sorunları Vakfi Yayını, Üçüncü Baskı, Ankara.

Ekonomi Bakanlığı, (2017). Uluslararası Doğrudan Yatırımlar2016 Yılı Raporu, Teşvik Uygulama Ve Yabancı Sermaye Genel Müdürlüğü, Ankara.

Gül, E., (2015). "GATT/WTO Çerçevesinde Uluslararası Ticaret ve Çevre İlişkisi”, http://dergipark.gov.tr/download/article-file/55286, (11.03.2018).

IISD ve UNEP. (2000). Environment and Trade: A Handbook, Canada, http://www.mfa.gov.tr/dunya-ticaret-orgutu-_dto_.tr.mfa (10.03.2018).

İktisadi Kalkınma Vakfi, (1998). Avrupa Birliği ve Türkiye'nin Çevre Politikalarının Karşılaştırılmalı İncelemesi, No:153, İstanbul.

İktisadi Kalkınma Vakfı, (1998). “Avrupa Birliği ve Türkiye’nin Çevre Politikalarının Karşılaştırılmalı İncelemesi”, No: 153, İstanbul. 
İriç, E. (2014). "Çerçevesinde Uluslararası Ticaret ve Çevre İlişkisi", http://www.istemiparman.com.tr/dto-cercevesinde-uluslararasi-ticaret-ve-cevre-iliskisi/, (20.02.2018).

Meydan Yıldız, S. G. (2016). "Çevre Bilinci ve Eko-Kent Planlaması: Gölbaşı Özel Çevre Koruma Bölgesi Örneği”, Ankara Üniversitesi, Sosyal Bilimler Enstitüsü, Yayınlanmamış Doktora Tezi, Ankara.

Ministry of Economy, (2018). http://www.foreigntrade.gov.tr/anl/dto/TURLAR-DTO.htm, (04.04.2017).

Kaplan, A. (1999). "Küresel Çevre Sorunları ve Politikaları", Yayın No: 19, Tezler Dizisi: 3 , Ankara: Mülkiyeler Birliği Vakfı Yayınları.

Karluk, R., Tonus Ö. (2015). "Küresel Ekonomik Örgütler”, Ed. Çınar Özen, Özgür Tonus, Uluslararası Örgütler, Eskişehir: Anadolu Üniversitesi Yayınları, s. 92-119.

Karluk, R. (2014). Uluslararası Kuruluşlar, İstanbul: Beta Yayınları.

Karluk, R. (2013). Uluslararası Ekonomi, İstanbul: Beta Yayınları.

Karluk, R. (1997). Dünya Ticaret Örgütü, Ankara: TOBB Yayınları.

Resmi Gazete, 29.1.1995, Say1: 2218.

Sutherland, P. vd. (2004). "The Future of the WTO: Addressing Institutional Challenges in the New Millenium" Report by the Consultative Board to the Director General Supachai Panitchpakdi. Geneva: WTO. http://www.wto.org/english/thewto_e/10anniv_e/future_wto_e.pdf, (10.03.2018).

Talu, N. (1995). “Çevre ve Ticaret Politikaları ve Türkiye'de Durum”, Yeni Türkiye Dergisi, Çevre Özel Sayıs1, Ankara.

TÜİK, (2018). İstatistiki Tablolar, http://www.tuik.gov.tr/PreTablo.do?alt_id=1046 (13.03.2018).

Türkiye Çevre Vakfi, (1995). GATT ve Çevre, Ankara.

Türkiye Çevre Sorunları Vakfı, (1988). Çevre ve Kalkınma İlişkileri, Ankara.

Yenipazarl1, A. (2003). Dünya Ticaret Örgütü (DTÖ), Gelişmekte Olan Ülkelerdeki Rolü, Önemi ve Türkiye, Adnan Menderes Üniversitesi Sosyal Bilimler Enstitüsü İktisat Anabilim Dalı Yayınlanmamış Yüksek Lisans Tezi, Nazilli.

Yılmaz, G. (2018). "28 Nisan 1998 tarihli MAİ Anlaşması”, http://docplayer.biz.tr/9213312-Maicok-tarafli-yatirim-anlasmasi.html, (20.02.2018).

WIR, (2017). Investment And The Digltal Economy, UNCTAD, United Nations Publication, Geneva,

https://www.yased.org.tr/ReportFiles/2017/Birle\%C5\%9Fmi\%C5\%9F\%20Milletler\%20Tic aret $\% 20 \mathrm{ve} \% 20 \mathrm{Kalk} \% \mathrm{C} 4 \% \mathrm{~B} 1 \mathrm{nma} \% 20 \% \mathrm{C} 3 \% 96 \mathrm{rg} \% \mathrm{C} 3 \% \mathrm{BCt} \% \mathrm{C} 3 \% \mathrm{BC} \% 20$ (UNCTAD) $\%$ 20D\%C3\%BCnya\%20Yat\%C4\%B1r\%C4\%B1m\%20Raporu\%20-\%202017.pdf, (15.03.2018).

WTO Dispute Settlement, (2018). http://www.wto.org/english/tratop_e/dispu_e/dispu_e.htm, (10.03.2018).

WTO Legal Texts, (2018). http://www.wto.org/english/docs_e/legal_e/legal_e.htm, (10.03.2018).

WTO, (2018). "MEA Database: Matrix of Trade Measures Pursuant to Selected MEAs", http://www.wto.org/english/tratop_e/envir_e/mea_database_e.htm, (10.03.2018).

WTO Primer, (2018). http://www.wto.org/english/thewto_e/whatis_e/tif_e/tif_e.htm, (10.03.2018).

WTO, "Understanding the WTO" http://www.wto.org/english/thewto_e/whatis_e/tif_e/tif_e.htm, (13.03.2018)

www.antimai.org.tr, (26.03.2018). 


\section{SUMMARY}

After World War II, in 1948 the "General Agreement on Tariffs and Trade" (GATT) came in to force with the strategy of redirecting the world trade. The main objective of GATT is to reduce custom duties which obstruct in this process and to convert them to tariff with liberalizing the structure of foreign trade. The approaches of developed countries to the environment as an actor of trade is the basic factor of the Multilateral Agreement on Investment's rule regulations with the influence of neoliberal policies and the globalization process. World Trade Organization's basic functions can be summarized as I) to ensure the implementation and administration of WTO agreements, II) to provide a forum environment for negotiations and to establish a mechanism for resolving disputes, III) to determine the trade rules concerning the transparency of the commercial measures used for environmental purposes and environmental policies which has commercial effect. Trade creates wealth that can be used to increase life welfare. Thus, while ensuring the effective use of renewable energy sources through the achievements that can be used for environmental development and the establishment of recycling systems to ensure less waste, it is possible to create a trading system that is easy to access eco-friendly technologies. The principles revealed by the World Trade Organization are defined as a system of a strong rules that all countries can adapt. As a matter of fact, WTO rules are very important in terms of being able to take place in the global competition market. While the concept of trade away from the global competitive market conserves national markets, domestic consumers' paying higher price, impoverishment, domestic companies' becoming distanced from innovation, entrepreneurship, technology etc. may be caused, and at the same time the commercial activities can not develop in line with environmental standards. In this study, trade policy, which is the basic component of the economy sector, and new policies and structures of the World Trade Organization related to the environment are explained using the literature review method. By examining the contracts made within the WTO, the measures taken to protect the environment is examined within the framework of the WTO establishment duties. 